\title{
WIĘCEJ ŻYCIA!
}

\section{AGATA BIELIK-ROBSON NA PUSTYNI. KRYPTOTEOLOGIE PÓŹNEJ NOWOCZESNOŚCI}

Mariusz Ferenc

W swej najnowszej książce Agata Bielik-Robson po raz kolejny staje w obronie człowieka i jego kruchej, narażonej na bezsensowne cierpienie, troskę i nieuchronną śmierć egzystencji jako bezwzględnie istotnych kategorii dyskursywnych. Czyni to jednak za pomoca nowego w stosunku do swoich wcześniejszych tekstów instrumentarium pojęciowego. O ile bowiem wcześniejszy Duch powierzchni stanowił przykład możliwości wykorzystania perspektywy literaturoznawczej w celu określenia warunków i zasad, na jakich podmiot ludzki może być zrehabilitowany w nieprzyjaznym elemencie filozofii posthumanistycznej, o tyle w „Na pustyni”. Kryptoteologiach późnej nowoczesności sięga autorka po teologię.

Należy zauważyć, że idzie przy tym pod prąd modzie - wszak teologia, ku której się zwraca, znacznie różni się do tej, w którą inwestują w ostatnich latach czołowi przedstawiciele lewicowej filozofii postsekularnej, dopatrujący się wybitnego teoriotwórczego potencjału w wybranych elementach chrześcijańskiej ortodoksji. Otóż teologia (lub kryptoteologia - oba te określenia funkcjonują w komentowanej książce niemal jako synonimy) proponowana przez Bielik-Robson jawnie dystansuje się od chrześcijaństwa i jego głównych idei, a skłania się zdecydowanie ku judaizmowi, który jest dla autorki Innej nowoczesności religia wzorcową (jeżeli nie jedyną godną tego miana).

Tylko judaizm (wraz z szeregiem swoich gnostyckich wcieleń) dostarcza najlepszych narzędzi pojęciowych do opisu przykrego położenia ludzkiej istoty względem natury, jak również pozwala na sformułowanie strategii obronnych, przynoszących namiastkę zbawienia. W przekonaniu autorki to właśnie judaizm, odpowiednio witalistycznie zreinterpretowany, najlepiej służy poszukiwaniu środków zaradczych, które mogłyby zaleczyć głęboką ranę skończoności w podmiocie ludzkim, a przynajmniej dać nadzieję na jej niedefinitywność. 
Niemniej jednak teologia jako dyskurs stanowiący remedium na egzystencjalne wybrakowanie człowieka, który stanowi jądro postulowanego przez Bielik-Robson konsolacyjnego projektu, nie wyczerpuje przedmiotu jej zainteresowań. Otóż sporą część „Na pustyni” stanowi demaskowanie kryptoteologicznych milczących założeń teorii określających nieprzyjazne człowiekowi filozoficzne oblicze nowoczesności oraz interpretacja jawnie teologicznych (w tym głównie gnostyckich) wątków, obecnych u tych myślicieli, u których autorka Innej nowoczesności zadłuża się, formułując postulaty ocalającego człowieka radzenia sobie z marnością jego kondycji. Podąża ona tym samym tropem wyznaczonym przez Waltera Benjamina w Tezach o filozofii historii, który zaproponował widzenie materializmu historycznego jako kukły do sterowania, na którą idealnie nadaje się brzydki karzeł teologii.

O ile jednak w paraboli Benjamina teologia miała gwarantować największe szanse na zwycięstwo materializmu historycznego w pojedynku szachowym $\mathrm{z}$ innymi filozofiami, o tyle $\mathrm{w}$ metodologicznej metaforze Bielik-Robson z usług teologii korzystaja wszyscy. Jest to konsekwencja fundującego wszelki dyskurs wyboru, wynikającego z osadzenia podmiotu ludzkiego w nieredukowalnej „matrycy negatywności”.

Człowiek, wedle autorki Ducha powierz̨chni, żyje w stanie oderwania od natury i separację tę postrzega jako bolesną ułomność - wieczny powrót tego samego i twarda, niedająca się przebić substancjalność bytu sprawiaja, że doświadczenie skończoności określa człowieka w sposób istotowy. Ukoronowaniem ludzkiego wybrakowania jest zaś śmierć i radykalna perspektywa, którą ona wnosi, a mianowicie zagłady jednostki ludzkiej w jej jednostkowości. Dlatego należy dokonać wyboru, który w skrócie ogranicza się do dwóch reakcji na wszechmocną i beznadziejną negatywność. Ponieważ dotyczy on rzeczy ostatecznych, tj. życia i śmierci, według Bielik-Robson ma on naturę teologiczną i jako taki stanowi bazę dla dyskursu w nim zakotwiczonego.

Wyjście pierwsze to pogodzenie się ze śmiercia, afirmacja negatywności, a tym samym kapitulacja, w ramach której życie poświęca samo siebie na ołtarzu bytu. Ten wybór jest dokonywany przez filozofię, którą autorka chce widzieć jako wyrafinowana rehabilitację mitu w jego najbardziej konsekwentnej, surowej i nieprzejednanej postaci; mitu wyrażającego się $\mathrm{w}$ fetyszystycznym uwielbieniu, jakim ontoteologicznie nastawiona filozofia darzy kamienną konkretność nieporuszonej substancjalności, będącej modelowa, a jednocześnie wrogą człowiekowi postacią bytu.

Jednocześnie ta fascynacja, której ulegać ma filozofia, przenikana jest przez niejawny, acz trwały i konsekwentny podziw dla krańcowej negatywności nawet nie tyle podmiotu, ale bytu w ogóle. Czarnym jądrem 
nowoczesnej metafizyki dla Bielik-Robson jest skryty zachwyt nad nicością, która zdaje się być ostateczną i prymarną warstwą, z której wyłania się byt raczej w wyniku kosmicznej pomyłki niż racjonalnego zamiaru. I ta pulsująca otchłań nieskończonej nicości staje się przedmiotem stłumionych popędów filozofii. Dlatego też określa autorka wewnętrznie skonfliktowana formację dyskursywną nowoczesnej filozofii jako religię śmierci, ucieleśniającą tryumf Tanatosa.

Do rzeczników tej specyficznej kryptoteologii podbudowującej filozofię zalicza Bielik-Robson zarówno Hegla - zwłaszcza odczytanego przez Aleksandra Kojeve'a - jak również uczniów i spadkobierców ideowych tego ostatniego, czyli Georges’a Bataille'a, Maurice’a Blanchota,Jacques’a Derridę, Giorgia Agambena, Paula De Mana, a w końcu również Jacques’a Lacana i Martina Heideggera. W teoriach i systemach wymienionych filozofów, błyskotliwie omówionych głównie w pierwszej części książki, autorka dopatruje się głębokiego urzeczenia śmiercią, a zwłaszcza jej wymiaru unicestwiającego wszelką podmiotową idiomatyczność.

Drugim członem fundamentalnej alternatywy, przed którym staje człowiek, jest wybór tego, co stanowi odwrotną stronę negatywności, wbrew i na przekór jej unicestwiającej mocy, czyli życia. Wybierając życie, właśnie to niepewne i kruche, pograżone $\mathrm{w}$ trosce i strachu o nie samo, podmiot ludzki wydaje walkę śmierci i wchodzi z nią w spór - z góry zresztą skazany na przegrana, przynajmniej z perspektywy skończoności fundującej sam akt wyboru, niemniej autentycznie ludzki.

Witalizm, którego rzeczniczką jest w swojej książce Bielik-Robson, jest żarliwym obstawaniem przy doczesnej, jednostkowej niedoskonałości człowieka. Jego religijnym symbolem jest biblijny Jakub, toczący walkę z Aniołem Śmierci i i otrzymujący odeń błogosławieństwo. Streszcza się ono w haśle „więcej życia!” przy którym autorka bezwzględnie obstaje, widząc w nim kamień węgielny, gwarant ostatecznego i trwałego wyjścia z marności ludzkiego położenia. Wprawdzie ostateczną zdobyczą w nieustającej walce o jednostkowa podmiotowość nie jest zbawienie i nieśmiertelność (to jawi się Agacie Bielik-Robson jako kontestacja życia pojedynczego w ogóle), niemniej po stronie zysków z tak zainscenizowanej konfrontacji podmiotu $z$ jego negatywnością należy uwzględnić niewątpliwie samopotwierdzenie, odwieczny cel wszelkich przedsięwzięć egzystencjalnych, dążących do ocalenia jednostkowej unikatowości.

$\mathrm{Na}$ rozmaite sposoby i w rozmaitych sferach dyskursywnych wyrażaja perspektywę i konsekwencje witalnego wyboru myśliciele, których dzieło Bielik-Robson obdarza najcieplejszymi uczuciami, czyli Allan Bloom,

\footnotetext{
${ }^{1}$ Takiego określenia używa A. Bielik-Robson. Według Biblii Tysiąclecia przeciwnikiem Jakuba jest sam Bóg, zaś według Tory w tłumaczeniu Rabina I. Cylkowa nieco bardziej enigmatyczna ,istota boska”.
} 
Zygmunt Freud i Walter Benjamin. Im to właśnie w dominujących partiach poświęcone są druga i trzecia część „Na pustyni”. Dokonując interpretacji ich koncepcji autorka kładzie główny nacisk na ich twardy i uparty sprzeciw wobec śmierci i potęgi negatywności, której mroczny urok jest im całkowicie obcy. A zatem niezależnie od tego, że ich dzieło wyraża się $\mathrm{w}$ dowartościowaniu niewiele ze sobą na pierwszy rzut oka mających perspektyw literackiego sporu (Bloom), oporu wobec popędu śmierci (Freud) i mesjanizmu (Benjamin), zdają się oni uczestniczyć w jednym witalistycznym projekcie, który przyczynia się do rewaluacji stłamszonych przez śmierć i jej dyskursywne wcielenia człowieka wraz z jego skończonością i pojedynczościa, które stanowią wartość bezwzględna, choć zarazem (a może właśnie dzięki temu) boleśnie kruchą.

Książce niniejszej przyświecaja przynajmniej trzy cele, a mianowicie: denuncjacja letalnej kryptoteologii, leżącej u podstaw dyskursu filozoficznego; następnie wypracowanie dyskursu, mogącego stanowić konkurencję dla tejże teologii i zakładanej przez nią wizji człowieka, który swój wyrok śmierci wydany przez byt powinien skwapliwie przyjąć i dobrowolnie mu się poddać; a w końcu realne i faktyczne zwycięstwo nad skamieniała postacia nowoczesnej, oddanej śmierci, humanistyki i tym samym realizacja witalizmu par excellance. $\mathrm{O}$ ile pierwsze dwa cele w mniejszym lub większym stopniu są osiagane przez to, co Bielik-Robson w komentowanej książce mówi, o tyle cel trzeci, stanowiący jej niewysłowioną ideę regulatywną, realizowany jest przez to, co autorka tą książką de facto robi.

Nie sposób podejmować szczegółowej dyskusji z interpretacjami filozofii, których autorka nie zawsze całkowicie życzliwie dokonuje na przestrzeni swojego monumentalnego eseju. Nie da się im odmówić błyskotliwości, jak również spójności oraz swoistej wnikliwości, która wszak musi być w naturalny sposób ograniczana przy dziełach obejmujących sobą tak szerokie, a jednocześnie skomplikowane i złożone spektrum tematyczne. Jakkolwiek nie zgadzamy się z niektórymi odczytaniami dokonanymi przez autorkę, niemniej nie jest rola niniejszej recenzji podejmowanie hermeneutycznego agonu. Dlatego chcielibyśmy się odnieść do tego, co naszym zdaniem przesądza o wysokiej wartości niniejszego eseju, a jednocześnie budzi największe kontrowersje z nim związane.

Otóż książka Bielik-Robson pomimo swojej uczoności i ciężaru erudycyjnego jest jednocześnie tekstem niebywale żarliwym i zaangażowanym. Rzadko się zdarza, aby te dwa cele były osiagane jednocześnie, a z pewnością jest to zjawisko rzadkie w humanistyce polskiej. Z reguły teksty w jej obrębie powstające, nawet te jawnie zaliczające się do eseistyki, są suche, wyprane z wszelkiego polotu i bez iskry bożej, czy to za sprawą braku zmysłu ironii, czy też z powodu cynizmu, jaki za nimi stoi, albo na odwrót, grzeszą tanim 
emocjonalizmem, który stawia pod znakiem zapytania ich dyskursywna doniosłość. Z komentowaną książką rzecz ma się odwrotnie. Otóż jest ona świadectwem głębokiego duchowego oddania, będącego gwarantem autentyczności propozycji teoretycznych w niej zawartych. Przebija z niej wyjątkowa, nienachalna, a jednocześnie wyraźnie obecna wiara w sens tego, co w niej napisane.

Prawdopodobnie w przypadku innej książki miałoby to znaczenie dużo mniejsze, ale tutaj, w tekście, który stawia w całej swej rozciagłości jedno, fundamentalnie bezkompromisowe pytanie o życie i śmierć, sama forma jego postawienia oraz sposób udzielenia nań odpowiedzi są kluczowe. To one bowiem decyduja, czy zostanie ono zbyte machnięciem ręki, czy też zdoła przyciagnąć dyskursywną uwage i sprowokuje teoretyczny namysł. Jednym słowem, udaje się autorce uniknąć performatywnej sprzeczności, jaką byłaby ostentacyjnie witalistyczna książka, całkowicie pozbawiona życia.

Jednocześnie przedsięwzięcie zainicjowane przez Bielik-Robson skazane jest na przegrana $\mathrm{i}$ autorka doskonale zdaje sobie $\mathrm{z}$ tego sprawę, sięgając po figurę kulejącego Jakuba jako metaforę ucieleśnianych swoim tekstem aspiracji. Historyczno-heurystyczny ciężar filozoficznych kategorii, pojęć i schematów pojęciowych, całego arsenału filozofemów po które sięga autorka, przyciaga w ostateczności witalistyczne wzloty do twardego bruku rzeczywistości tekstu filozoficznego. Teologia, pomimo że atrakcyjnie zrewaloryzowana moca natchnionego odczytania kluczowych dla współczesnej humanistyki tekstów, musi wycofać się na swoje zmarginalizowane pozycje. Dzieje się tak za sprawą fundamentalnego wykluczenia, jakie spotyka egzystencjalną prawdę, starającą się o inkorporację do sfery dyskursu.

Z pewnością ta porażka nie przekreśla „Na pustyni” i nie sprawia, że wysiłki autorki, zmierzające do wprowadzenia w łono dyskursu filozoficznego agonicznej względem jego prerogatyw i dążności perspektywy, są pozbawione wartości. Wprost przeciwnie, stanowią one ożywczy impuls, bez którego filozofia osuwa się w otchłań formalnej i abstrakcyjnej, czczej pychy. Filozofia w ostateczności nie może się wszak obejść bez wewnętrznego sprzeciwu, bez dynamiki i namiętności, które funduja jej konkretność. Ta książka, będąca pięknym gestem świadomego swej skończoności życia, w pełni tę prawdę potwierdza. 